\title{
Trichomonas vaginalis Enfeksiyonu Tanısında Mikroskobik İnceleme, Kültür ve Polimeraz Zincir Reaksiyonu Testlerinin Değerlendirilmesi
}

\author{
Evaluation of Microscopic Examination, Culture and \\ Polymerase Chain Reaction Tests in the Diagnosis of \\ Trichomonas vaginalis Infection
}

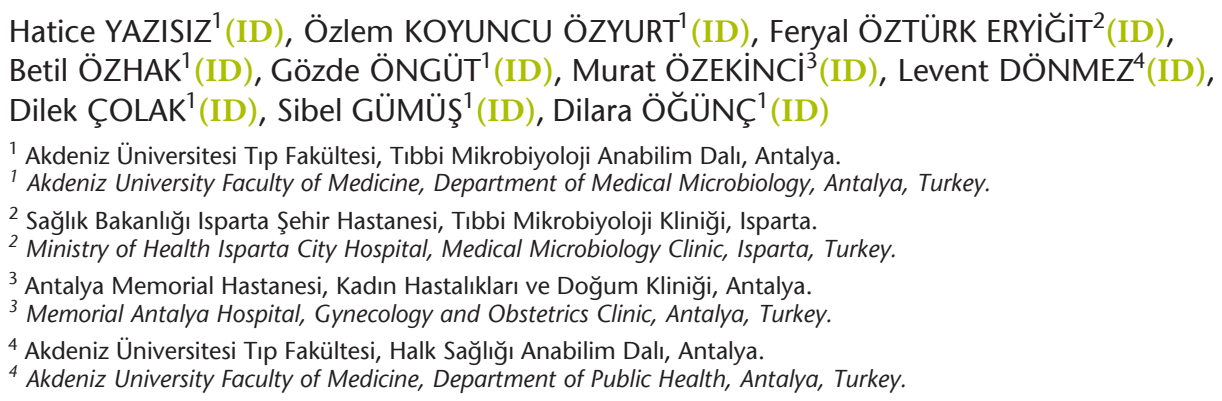

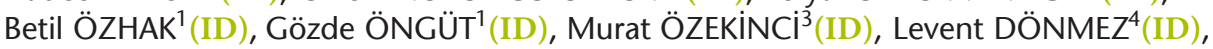
Dilek ÇOLAK

${ }^{1}$ Akdeniz Üniversitesi Tıp Fakültesi, Tıbbi Mikrobiyoloji Anabilim Dalı, Antalya.

${ }^{1}$ Akdeniz University Faculty of Medicine, Department of Medical Microbiology, Antalya, Turkey.

2 Sağlık Bakanlığı Isparta Şehir Hastanesi, Tıbbi Mikrobiyoloji Kliniği, Isparta.

${ }^{2}$ Ministry of Health Isparta City Hospital, Medical Microbiology Clinic, Isparta, Turkey.

${ }_{3}^{3}$ Antalya Memorial Hastanesi, Kadın Hastalıkları ve Doğum Kliniği, Antalya.

${ }^{3}$ Memorial Antalya Hospital, Gynecology and Obstetrics Clinic, Antalya, Turkey.

${ }^{4}$ Akdeniz Üniversitesi Tıp Fakültesi, Halk Sağlığı Anabilim Dalı, Antalya.

${ }^{4}$ Akdeniz University Faculty of Medicine, Department of Public Health, Antalya, Turkey.

* Bu çalışma, Akdeniz Üniversitesi Bilimsel Araştırma Projeleri Yönetim Birimi tarafından desteklenmiştir (Proje no: TTU2015-843).

** Bu çalışmanın ön verileri, 20. Ulusal Parazitoloji Kongresi (25-29 Eylül 2017, Eskişehir)'nde poster ve Uluslararası 38. Türk Mikrobiyoloji Kongresi (4-8 Kasım 2018, Antalya)'nde sözel bildiri olarak sunulmuștur.

Makale Atıfı: Yazısız H, Koyuncu Özyurt Ö, Öztürk Eryiğit F, Özhak B, Öngüt G, Özekinci M ve ark. Trichomonas vaginalis enfeksiyonu tanısında mikroskobik inceleme, kültür ve polimeraz zincir reaksiyonu testlerinin değerlendirilmesi. Mikrobiyol Bul 2020;54(1):135-143.

\section{öz}

Cinsel yolla bulaşan enfeksiyonlar (CYBE), tüm dünyada halk sağlığı sorunu olarak önem taşımaktadır. Klinik ve laboratuvar tanı sorunları nedeniyle CYBE'leri önleme ve kontrol programlarında bazı zorluklar bulunmaktadır. Chlamydia trachomatis enfeksiyonları, trikomoniyaz ve gonore yaygın görülen CYBE'lerdir. Bu çalışmada, Akdeniz Üniversitesi Hastanesi Kadın Hastalıkları ve Doğum Polikliniğine başvuruda bulunan ve vajinal akıntısı olan kadınlarda Trichomonas vaginalis enfeksiyonu tanısında direkt mikroskobik inceleme, kültür ve polimeraz zincir reaksiyonu (PCR) testlerinin değerlendirilmesi, akıntıya neden olabilecek diğer mikrobiyolojik etkenlerin saptanması ve çeşitli sosyal değişkenleri değerlendirmek amaçlanmıştır. Çalışmaya sosyodemografik özellikleri kayıt edilen 215 hasta dahil edilmiştir. Hastalardan alınan vajinal/endoservikal sürüntü örnekleri mikroskobik inceleme ile değerlendirilmiştir. Bakteriyel kültür amacıyla alınan sürüntü örnekleri kanlı agar, MacConkey agar ve çikolata agar besiyerlerine ekilmiştir. Trichomonas spp. kültürü için \%5 at serumu eklenmiş modifiye trichosel buyyon (Becton Dickinson, ABD) besiyeri kullanılmıştır. Sürüntü ör- 
Trichomonas vaginalis Enfeksiyonu Tanısında Mikroskobik Inceleme, Kültür ve Polimeraz Zincir Reaksiyonu Testlerinin Değerlendirilmesi

neklerinde C.trachomatis, Neisseria gonorrhoeae, T.vaginalis varlığı multipleks PCR (BD Max CT/GC/TV, Becton Dickinson, ABD) ile araştırılmıştır. Toplam 65 (\%30.3) örnekte en az bir patojen tespit edilmiştir. İki yüz on beş hastanın 4 (\%1.9)'ünde mikroskobik inceleme ve PCR ile T.vaginalis saptanmıştır. Hasta örneklerinin 21 (\%9.8)'inde mikroskobik inceleme ile maya morfolojisinde mantar izlenmiştir. Nugent skorlama sistemine göre 24 (\%11.2) hastaya mikroskobik olarak bakteriyel vajinozis tanısı konulmuştur. Otuz iki (\%14.9) örnekte Candida türleri, 2 (\%0.9) örnekte Streptococcus agalactiae üremesi olmuştur. PCR yöntemi ile 2 (\%0.9) örnekte C.trachomatis, 1 (\%0.5) örnekte N.gonorrhoeae saptanmıştır. Bu çalışmadaki hastaların \%95.3'ünün evli olduğu, \%96.7'sinin şimdiye kadar cinsel partner sayısının tek olduğu belirlenmiştir. İki veya daha fazla gebelik geçmişi olan kadınlarda patojen saptanma oranı istatistiksel olarak anlamlı düzeyde daha yüksek bulunmuştur $(\mathrm{p}<0.05)$. Çalışmamızda vajinal akıntısı olan kadınlarda PCR yöntemi ile T.vaginalis ile birlikte N.gonorrhoeae ve C.trachomatis araştırılmıştır. Multipleks PCR yönteminin kullanılması hasta örneklerinde birden fazla patojenin eş zamanlı olarak saptanmasına olanak sağlamıştır.

Anahtar kelimeler: Chlamydia trachomatis; cinsel yolla bulaşan enfeksiyonlar; Neisseria gonorrhoeae; Trichomonas vaginalis.

\section{ABSTRACT}

Sexually transmitted infections (STIs) are important as a public health problem all over the world. There are some difficulties in prevention and control programs of STIs due to clinical and laboratory diagnostic problems. The most common STIs are Chlamydia trachomatis infections, trichomoniasis and gonorrhea. The study aimed to investigate the direct microscopic examination, culture and polymerase chain reaction (PCR) tests in the diagnosis of Trichomonas vaginalis infection; to determine other microbiological agents that may cause vaginal discharge and to evaluate the various social variables in women with vaginal discharge admitted to the outpatient clinic of Obstetrics and Gynecology in Akdeniz University Hospital. Two hundred and fifteen patients were enrolled in the study. The socio-demographic features of the patients were recorded. Vaginal/endocervical swab specimens taken from patients were evaluated by microscopic examination. Swab specimens were inoculated into blood agar, MacConkey agar and chocolate agar for bacterial culture. Modified Trichosel broth with 5\% horse blood (Becton Dickinson, USA) was used for Trichomonas spp. culture. The presence of C.trachomatis, Neisseria gonorrhoeae, and T.vaginalis in swab samples were investigated by multiplex PCR assay (BD Max CT/GC/TV, Becton Dickinson, USA). At least one pathogen was detected among 65 (30.3\%) samples. T.vaginalis was detected by microscopic examination and PCR in four of 215 (1.9\%) patients. Existence of yeast morphology was observed in 21 (9.8\%) specimens by microscopic examination. Twenty four (11.2\%) patients were diagnosed as bacterial vaginosis microscopically according to Nugent score system. Candida species grew in 32 (14.9\%) and Streptococcus agalactiae grew in $2(0.9 \%)$ of the specimens. C.trachomatis was detected in $2(0.9 \%)$ samples and N.gonorrhoeae in $1(0.5 \%)$ sample by PCR. In this study, $95.3 \%$ of the patients were married and $96.7 \%$ had only one sexual partner in the mean time. The rate of detection of pathogens were statistically higher in women who have had two or more pregnancies $(\mathrm{p}<0.05)$. In our study, T.vaginalis together with N.gonorrhoeae and C.trachomatis were investigated by PCR method in women with vaginal discharge. The use of multiplex PCR test allowed simultaneous investigation of multiple pathogens in the patient samples.

Keywords: Chlamydia trachomatis; Neisseria gonorrhoeae; sexually transmitted infection; Trichomonas vaginalis.

\section{Gíriş}

Trikomoniyaz, Trichomonas vaginalis'in neden olduğu cinsel yolla bulaşan enfeksiyon (CYBE)'dur'. Dünyada en yaygın viral olmayan CYBE olmasına rağmen, uzun yıllar boyunca büyük ölçüde göz ardı edilmiştir ${ }^{2}$. CYBE'lerin klinik ve laboratuvar tanılarında yaşanan güçlükler nedeniyle hastalığı önleme ve kontrol programlarında zorluklar yaşanmaktadır ${ }^{3}$. "Centers for Disease Control and Prevention (CDC)"ın Şubat 2013 tarihinde yayımladığı analize göre Amerika Birleşik Devletleri'nde yıllık 20 milyon yeni CYBE olduğu tahmin edilmektedir. Bu verilere göre, insan papilloma virüs (HPV)'den sonra sırasıyla 
Chlamydia trachomatis enfeksiyonları, trikomoniyaz ve gonore en sık rastlanan enfeksiyonlardır ${ }^{4}$. CYBE'lerin prevalansı çalışmaya katılan popülasyon ve etken patojenlerin izolasyon yöntemlerine göre değişkenlik göstermektedir. Türkiye'de yapılan çalışmalarda T.vaginalis görülme sıklığı \%0.3 ile \%9 arasında değişen oranlarda bildirilmiştir ${ }^{5-9}$.

T.vaginalis tanısında kadınlarda vajinal akıntıdan direkt mikroskobik inceleme en yaygın kullanılan yöntemdir. Kültür yöntemleri göreceli olarak ucuz yöntemler olmakla birlikte deneyimli bir mikrobiyolog tarafından değerlendirilmesi gerekmekte ve tanımlama için bir haftadan fazla zamana gereksinim bulunmaktadır. Bu yöntemler dışında mikroorganizmanın doğrudan tespit edilmesini sağlayan ticari antijen testleri bulunmaktadır. Bu testlerde örnek toplama zamanı ile testin gerçekleştirilmesi arasında geçen zaman daha uzundur. Polimeraz zincir reaksiyonu (PCR) ve transkripsiyon aracılı amplifikasyon temelli nükleik asit amplifikasyon testlerinin kültür, mikroskobik inceleme, antijen testleri, nükleik asit prob testlerine göre analitik duyarlılığı yüksektir (\%76-100). Bu testler, özellikle klinik örnekte az mikroorganizmanın olduğu asemptomatik kadın ve erkeklerde yapılacak tarama için uygundur ${ }^{10}$. Kültür yöntemleri ile tespit edilemeyen olgularda PCR ile T.vaginalis tespit edilebilmektedir ${ }^{11}$. Testin gerçekleştirilmesi sırasında canlı mikroorganizmaya gereksinim bulunmaması nedeniyle, örneğin alınması ve laboratuvara nakli sırasında ortaya çıkan süre ve sıcaklık değişiklikleri önemli olmamaktadır. Bu durum, epidemiyolojik çalışmalar için tarama yapıımasına olanak sağlar ${ }^{10}$.

Bu çalışmada, Akdeniz Üniversitesi Hastanesi Kadın Hastalıkları ve Doğum Polikliniğine gelen vajinal akıntısı olan kadınlarda T.vaginalis enfeksiyonu tanısında direkt mikroskobik inceleme, kültür ve PCR testlerinin değerlendirilmesi, akıntıya neden olabilecek diğer etkenlerin saptanması ve sonuçların uygulanan sosyodemografik anket formlarıla birlikte çeşitli sosyal değişkenler açısından değerlendirilmesi amaçlanmıştır.

\section{GEREÇ ve YÖNTEM}

Bu çalışma, Akdeniz Üniversitesi Tıp Fakültesi Klinik Araştırmalar Etik Kurulu onayı ile gerçekleştirildi (Tarih: 18.03.2015 ve Karar no: 122).

\section{Hastaların Seçimi}

Çalışmaya Kadın Doğum Polikliniğinde muayene edilen, vajinal akıntı şikayeti olan veya muayene sırasında vajinal akıntı saptanan, bilgilendirilmiş gönüllü onamları alınan, 18 yaş üzeri 215 hasta dahil edildi.

Gönüllülerin yaşı, medeni durumu, ilk cinsel ilişki yaşı, gebelik/doğum sayısı, semptomların süresi, şimdiye kadar olan seksüel partner sayısı, son 12 aydaki partner sayısı, kondom kullanım sıklığı sorgulanarak kayıt edildi. Pelvik ağrı, vajinal kaşıntı, idrar yapma zorluğu gibi klinik bulgular ve jinekolojik muayene bulguları kayıt edildi.

\section{Örneklerin Alınması ve Saklanması}

Mikroskobik inceleme ve kültür için hastalardan alınan vajinal/endoservikal sürüntü örnekleri uygun transport koşullarında laboratuvara ulaştırıldı. PCR testi için üretici firma- 
nın kitle beraber temin ettiği eküvyonlar ile örnek alındı. Örneğin alındığı eküvyon BD MAX UVE tampon çözeltili örnek tüpüne aktarıldı ve çalışılana kadar $+4^{\circ} \mathrm{C}^{\prime}$ de (en fazla beş gün) veya $-20^{\circ} \mathrm{C}^{\prime}$ de (en fazla 30 gün) saklandı.

\section{Direkt ve Boyalı Mikroskobik İnceleme}

Mikroskobik değerlendirme için yayma preparatları hazırlandı. Bir lam örneği serum fizyolojik ile hazırlanarak x400 büyütmede incelendi. Diğer iki adet yayma Gram ve Giemsa boyası ile boyanarak x1000 büyütmede incelendi. Gram boyalı yaymalar bakteriyel vajinoz açısından Nugent skorlama yöntemi ile değerlendirildi.

\section{Kültür}

Laboratuvara ulaşan sürüntü örneklerinden kanlı agar, MacConkey agar, çikolata agar ve Sabouraud dekstroz agar besiyerlerine ekim yapıldı. Ekim yapılan plaklar $37^{\circ} \mathrm{C}$ 'de inkübe edildi ve 24-48 saat sonra değerlendirildi. Kültürde üreyen koloniler Gram boyama ile değerlendirildi. Maya morfolojisinde mantar izolatları konvansiyonel yöntemler (Germ tüp testi, CHROMAgar ve corn meal tween 80 agar besiyerlerine ekimleri yapılarak), BD Phoenix (Becton Dickinson, İngiltere) otomatize tanımlama sistemi ve "matrix-assisted laser desorption/ionization time of flight (MALDI-TOF MS)" (Bruker Daltonik GmbH, Bremen, Almanya) ile üretici firmanın önerileri doğrultusunda çalışılarak tanımlandı. Bakteri izolatlarının tanımlanmasında BD Phoenix otomatize tanımlama sistemi kullanıldı.

Sürüntü örneğinden Trichomonas spp. izolasyonu için \%5 at serumu eklenmiş modifiye trichosel buyyon (Becton Dickinson, ABD) besiyerine ekim yapıldı. Ekim yapılan besiyerleri $37^{\circ} \mathrm{C}^{\prime}$ de inkübe edildi. Kültürlerden direkt mikroskobik inceleme için preparat hazırlanarak, beş gün boyunca her gün inceleme yapılarak hareketli Trichomonas'ların varlığı araştırıldı.

\section{Polimeraz Zincir Reaksiyonu}

BD Max sistemi ile çalışılan BD Max CT/GC/TV (Becton Dickinson, ABD) otomatize multipleks moleküler testi kullanılarak C.trachomatis, Neisseria gonorrhoeae ve T.vaginalis varlığı araştırıldı. Test üretici firmanın önerileri doğrultusunda çalışıldı. Çalışma sonunda, BD Max sistemi bilgisayar programı tarafından otomatik olarak, hedef ve internal kontrol amplifikasyonunu temel alarak, negatif, pozitif ve geçersiz sonuç olarak verilen test sonuçları değerlendirildi.

\section{İstatistiksel Analiz}

İstatistiksel analizler Windows SPSS 13.0 programı (SPSS Inc., Chicago, IL, USA) kullanılarak yapıldı. Örneklerin tanımlanması ve sonuçların değerlendirilmesi için tanımlayıcı istatistikler kullanıldı. Tüm numerik veriler sıklık ve yüzde olarak ifade edildi. Kategorik veriler ki-kare testi ile karşılaştırıldı. İstatistiksel anlamlılık için p değeri < 0.05 kabul edildi.

\section{BULGULAR}

Çalışmaya alınan, ortalama yaşları $42.4 \pm 11.1$ yıl olan 215 hastanın ayrıntılı demografik bilgileri Tablo I’de gösterilmiştir. 


\begin{tabular}{|c|c|c|c|c|c|}
\hline & Sayı & Yüzde & & Sayı & Yüzde \\
\hline Medeni durum & & & Kondom kullanım sıklığı & & \\
\hline Evli & 205 & 95.3 & Her zaman & 22 & 10.2 \\
\hline \multirow[t]{2}{*}{ Bekar } & 10 & 4.7 & Nadiren & 35 & 16.3 \\
\hline & & & Kullanmayan & 158 & 73.5 \\
\hline Şimdiye kadar partner sayısı & & & Kaşıntı & & \\
\hline Bir & 208 & 96.7 & Var & 88 & 40.9 \\
\hline İki ve üzeri & 7 & 3.3 & Yok & 127 & 59.1 \\
\hline Son bir yıl içinde partner sayısı & & & İdrar yapmada zorluk & & \\
\hline Bir & 209 & 97.2 & Var & 42 & 19.5 \\
\hline İki ve üzeri & 6 & 2.8 & Yok & 173 & 80.5 \\
\hline Gebelik sayısı & & & Pelvik ağrı & & \\
\hline $0-1$ & 61 & 28.4 & Var & 135 & 62.8 \\
\hline $2-4$ & 132 & 61.4 & Yok & 80 & 37.2 \\
\hline$\geq 5$ & 22 & 10.2 & & & \\
\hline illk seks yaşı & & & Akıntı rengi & & \\
\hline$\leq 16$ & 19 & 8.8 & Sarı & 65 & 30.2 \\
\hline $17-20$ & 69 & 32.0 & Yeşil & 7 & 3.2 \\
\hline $21-25$ & 67 & 31.2 & Beyaz & 45 & 20.9 \\
\hline$\geq 25$ & 60 & 27.9 & Renksiz/Şeffaf & 98 & 45.6 \\
\hline
\end{tabular}

Direkt mikroskobik inceleme ile 4 (\%1.9) örnekte T.vaginalis trofozoitleri görülmüştür. Boyalı mikroskobik incelemede, örneklerin \%59.5'i normal vajen florası olarak değerlendirilmiştir. Örneklerin 43 (\%20.0)'ünde polimorfonükleer lökosit saptanmıştır. Nugent skorlama sistemine göre 24 (\%11.2) hasta bakteriyel vajinozis olarak değerlendirilirken, olguların 21 (\%9.8)'inde maya morfolojisinde mantar görülmüştür.

Kültürde, 32 (\%14.9) örnekte Candida spp. [C.krusei $(\mathrm{n}=3)$, C.glabrata $(\mathrm{n}=10)$, C.albicans $(n=11)$, C.kefyr $(n=2)$, C.parapsilosis $(n=1)$, Saccharomyces cerevisiae $(n=1)$, Candida spp. $(\mathrm{n}=3)$, C.tropicalis $(\mathrm{n}=1)], 2$ (\%0.9) örnekte Streptococcus agalactiae üremiştir. Trichomonas spp. izolasyonu için yapılan kültürlerde üreme saptanmamıştır.

PCR yöntemi sonucunda örneklerin 4 (\%1.9)'ünde T.vaginalis, 2 (\%0.9)'sinde C.trachomatis, 1 (\%0.5)'inde N.gonorrhoeae saptanmıştır.

İki yüz on beş hastanın 4 (\%1.9)'ünde mikroskobik inceleme ve PCR çalışması ile T.vaginalis tespit edilmiştir. Bu hastaların yaşları 34, 47, 49 ve 57 olarak belirlenmiştir. Hastaların ikisinde vajinal kaşıntı, birinde dizüri, birinde kötü kokulu akıntı şikayeti olduğu saptanmıştır.

Hastaların tüm sonuçları değerlendirildiğinde; \%14.9'unda Candida türleri, \%11.2'sinde Nugent skorlama sistemine göre bakteriyel vajinozis, \%1.9'unda T.vaginalis, 


\begin{tabular}{|c|c|c|c|c|}
\hline Değişken & Sayı & $\begin{array}{c}\text { Patojen olan kişi/ } \\
\text { örnek sayısı }\end{array}$ & Yüzde & $\mathbf{p}^{*}$ \\
\hline \multicolumn{5}{|l|}{ Yaş grupları } \\
\hline$<40$ yaş & 93 & 32 & 34.4 & \\
\hline 41 yaş + & 122 & 33 & 27.0 & 0.244 \\
\hline \multicolumn{5}{|l|}{ Gebelik sayısı } \\
\hline 0-1 gebelik & 61 & 11 & 18.0 & \\
\hline 2 gebelik + & 154 & 54 & 35.1 & 0.014 \\
\hline \multicolumn{5}{|l|}{ İlk cinsel ilişki yaşı } \\
\hline 18 yaş + & 186 & 54 & 29.0 & \\
\hline$<18$ yaş & 29 & 11 & 37.9 & 0.322 \\
\hline \multicolumn{5}{|c|}{ Kondom kullanma durumu } \\
\hline Kullanmayan & 158 & 42 & 26.6 & \\
\hline Kullanan & 57 & 23 & 40.4 & 0.052 \\
\hline \multicolumn{5}{|l|}{ Medeni durum } \\
\hline Bekar & 10 & 3 & 30.0 & \\
\hline Evli & 205 & 62 & 30.2 & 0.987 \\
\hline \multicolumn{5}{|l|}{ Partner sayısı } \\
\hline 1 & 208 & 63 & 30.3 & \\
\hline $2+$ & 7 & 2 & 28.6 & 0.922 \\
\hline
\end{tabular}

$\% 0.9^{\prime}$ unda C.trachomatis, \%0.9'unda S.agalactiae, \%0.5'inde N.gonorrhoeae olmak üzere, \%30.3'ünde patojen olabilecek bir etken tespit edilmiştir. Patojen saptanan olguların sosyodemografik özelliklerinin dağılımı Tablo II'de gösterilmiştir. İki ve üzerinde gebeliği olanlarda istatistiksel olarak anlamlı düzeyde daha yüksek patojen saptanmıştır.

\section{TARTIŞMA}

T.vaginalis insanlarda ürogenital sistemde görülen, kadınlarda vajinada yerleşen bir parazittir. Trikomoniyaz asemptomatik seyredebilmekle birlikte enfekte kişilerde vajinit, üretrit ve servisit gelişebilmektedir ${ }^{5,12}$. Tedavi edilmeyen enfeksiyonlar pelvik enflamatuvar hastalık, insan immün yetmezlik virüsü (HIV)'ne karşı artan duyarlılık ve obstetrik komplikasyonlar gibi sekellere neden olabilmektedir ${ }^{13}$. Dirençli vajinal akıntısı olan 156 hastanın tarandığı bir çalışmada T.vaginalis \%2.6 oranında tespit edilirken ${ }^{14}$, vajinit yakınması olan Türkiye'ye göç etmiş Suriyeli kadınlarda \%36 oranında bulunmuştur ${ }^{15}$. T.vaginalis enfeksiyonlarının, sosyoekonomik durum, yaşam koşulları, göç, cinsel aktivitenin erken yaşta başlaması ve çoklu partner ile ilişki gibi nedenlere bağlı olarak artış gösterdiği bilinmektedir ${ }^{16}$. Çeşitli faktörler araştırma sonucunu etkilemekle beraber ülkemizde yapılan çalışmalarda yıllar içinde bir düşme olduğu görülmektedir ${ }^{14,17,18}$. 
Çalışmamızda, hastanemizin Kadın Hastalıkları ve Doğum Polikliniğine başvuran, vajinal akıntısı olan kadınlardan alınan örneklerin 4 (\%1.9)'ünde T.vaginalis tespit edilmiştir. Hasta grubumuzda, 16 yaş ve altında cinsel aktif olan kadınların oranı \%8.8 olup hastaların \%95.3'ünün evli, \%96.7'sinin şimdiye kadar olan partner sayısı tek ve \%97.2'sinin son bir yıl içinde partner sayısı tek olan kadınlar olduğu belirlenmiştir. Çalışmamızda T.vaginalis saptama oranımızın düşük olmasının bu faktörlere bağlı olabileceğini düşünüyoruz. T.vaginalis saptama oranımız düşük (\%1.9) olmasına rağmen, bu çalışma bizim bölgemizdeki vajinal akıntısı olan kadınlarda T.vaginalis araştıılan ilk çalışmadır. Bu nedenle sonuçlarımızın bu konuda yapılacak olan araştırmalara yol gösterici olacağını düşünüyoruz.

T.vaginalis enfeksiyonu tanısı serum fizyolojik ile direkt mikroskobik inceleme ve kültür yöntemlerinin sonuçlarını değerlendiren uzmanın mikroskop deneyimine ve protozoonların canlı olarak korunmasına bağlı olarak değişmektedir ${ }^{19}$. PCR yöntemi potansiyel olarak daha kısa sürede yüksek duyarlılık ve özgüllükte sonuç alma avantajı sunmaktadır ${ }^{20}$. Bruni ve arkadaşlarının yaptığı bir çalışmada², Aptima TV testi, kültür, direkt mikroskobik inceleme, Gram boyalı mikroskobik inceleme ile T.vaginalis sırasıyla \%4.2, \%2.4, \%1.2 ve \%0 oranında tespit edilmiştir. BD Max CT/GC/TV (Becton Dickinson, ABD) otomatize multipleks moleküler testi kullanılarak yapılan bir çalışmada ${ }^{21}$ T.vaginalis'in saptanmasında bu testin duyarlılı̆ı \%96.1 olarak bulunmuştur. Çalışmamızda direkt mikroskobik inceleme, boyalı mikroskobik inceleme, kültür ve PCR yöntemleri ile T.vaginalis araştırılmıştır. Bu yöntemlerle T.vaginalis tespit oranı sırasıyla \%1.9, \%1.9, \%0, \%1.9 olarak bulunmuştur. PCR yöntemi ve mikroskobik inceleme ile T.vaginalis saptanan iki örnekte teknik sorunlar nedeniyle kültür yapılamamış, iki örnekte ise örneklerin laboratuvara geç ulaşması nedeniyle üreme saptanmamıştır.

Bakteriyel vajinozis, kadınlarda vajinal akıntı ve kokunun en yaygın nedenidir. Bakteriyel vajinozis tanısında altın standart Gram boyama ve Nugent skorlamasıdır ${ }^{22}$. İstanbul'da 386 hastada yapılan bir çalışmada ${ }^{23} \% 15.2$, Ankara'da yapılan bir çalışmada ${ }^{24} \% 9$ oranında bakteriyel vajinozis tespit edilmiştir. Çalışmamızda vajinal akıntısı olan hastaların 24 (\%11.2)'ü bakteriyel vajinozis olarak değerlendirilmiş olup bulgumuz yapılan diğer çalışmalarla uyumludur. Kandidiyazis kadınlarda ortaya çıkan akıntı nedenlerinden biri olup vajinitlerin en sık ikinci sebebidir ${ }^{25}$. Candida türleri, Keşli ve arkadaşları tarafından yapılan bir çalışmada ${ }^{6}$, vajinal akıntı şikayeti ile başvuran ve jinekolojik muayene sırasında akıntı saptanan hastalarda \%16, diğer bir çalışmada ${ }^{23}$ kadın hastalıkları ve jinekoloji polikliniğine başvuran hastalarda \%19.9 ve Ankara'da yapılan diğer bir çalışmada ${ }^{24}$ ise vajinit yakınmasıyla gelen hastalarda \%42 oranlarında tespit edilmiştir. Kandidiyazis çalışmamızda \%9.8 oranında bakteriyel vajinozisden sonra ikinci sıklıkta bulunmuştur.

Sunulan çalışmada otomatize multipleks moleküler bir test olan BD Max CT/GC/TV kiti kullanılarak aynı zamanda C.trachomatis ve N.gonorrhoeae araştırılmıştır. Türkiye'de yapılan çeşitli çalışmalarda farklı sonuçlar saptanmıştır. Ortaylı ve arkadaşlarının yaptığı bir çalışmada ${ }^{26}$ N.gonorrhoeae tespit edilememiş olup, Açık ve arkadaşlarının çalışmasın$\mathrm{da}^{27}$ gönüllü kürtaj yapılan kadınlarda \%1.7 oranında saptanmıştır. Eksi ve arkadaşlarının yaptığı çalışmada ${ }^{28}$, semptomatik kadınlarda \%2.4, infertil kadınlarda \%1.0 oranında 
N.gonorrhoeae saptanırken asemptomatik kadınlarda saptanmamıştır. Dirençli akıntısı olan hastalarda yapılan başka bir çalışmada ise, \%6.4 oranında N.gonorrhoeae tespit edilmiştir $^{14}$. C.trachomatis saptanma oranı hayat kadınlarında \%3.6, infertil kadınlarda \%5.6 oranında bulunmuştur ${ }^{29,30}$. Bir başka çalışmada ise, semptomatik ve asemptomatik kadınlarda prevalans sırasıyla \%5.2 ve \%1.1 olarak tespit edilmiştir ${ }^{28}$. Dirençli akıntısı olan hastaların alındığı çalışmada \%3.2 oranında C.trachomatis saptanmıştır ${ }^{14}$. Çalışmamızda vajinal akıntısı olan kadınlarda PCR yöntemi ile N.gonorrhoeae \%0.5, C.trachomatis \%0.9 oranında saptanmıştır. T.vaginalis saptanan örneklerde, çeşitli nedenlerle kültürde üreme olmaması bu çalışmanın kısıtlı tarafını oluşturmaktadır.

Sonuç olarak, 215 hastanın 4 (\%1.9)'ünde mikroskobik inceleme ve PCR ile T.vaginalis tespit edilmiştir. Çalışmamızda vajinal akıntısı olan kadınlarda multipleks moleküler test kullanılması ile T.vaginalis'in yanı sıra N.gonorrhoeae ve C.trachomatis'in eş zamanlı olarak saptanması mümkün olmuştur. Multipleks PCR yönteminin kullanılması hasta örneklerinde birden fazla patojenin eş zamanlı olarak saptanmasına olanak sağlamaktadır.

\section{ÇIKAR ÇATIŞMASI}

Yazarlar bu makale ile ilgili herhangi bir çıkar çatışması bildirmemişlerdir.

\section{KAYNAKLAR}

1. Leli C, Castronari R, Levorato L, Luciano E, Pistoni E, Perito S, et al. Molecular sensitivity threshold of wet mount and an immunochromatographic assay evaluated by quantitative real-time PCR for diagnosis of Trichomonas vaginalis infection in a low-risk population of childbearing women. Infez Med 2016;24(2):112-6.

2. Bruni MP, Freitas da Silveira M, Stauffert D, Bicca GLO, Caetano Dos Santos C, da Rosa Farias NA, et al. Aptima Trichomonas vaginalis assay elucidates significant underdiagnosis of trichomoniasis among women in Brazil according to an observational study. Sex Transm Infect 2019;95(2):129-32.

3. Ünal S, Zarakolu IP. Cinsel yolla bulaşan enfeksiyonlar ve genel özellikleri, p: 1549. In: Topcu AW, Söyletir G, Doğanay M (eds). Enfeksiyon Hastalıkları ve Mikrobiyolojisi 2008, 3. Baskı. Nobel Tıp Kitapevi, İstanbul.

4. Centers for Disease Control and Prevention. Incidence, prevalence, and cost of sexually transmitted infections in the United States. https://www.cdc. gov/nchhstp/Newsroom Feb 2013.

5. Ertabaklar H, Yaman Karadam S, Malatyalı E, Ertuğ S. Investigation of in vitro metronidazole resistance in the clinical isolates of Trichomonas vaginalis. Mikrobiyol Bul 2016;50(4):552-8.

6. Keşli R, Pektaş B, Özdemir M, Günenc O, Coşkun E, Baykan M, et al. Microscopic examination of vaginal discharge specimens for Trichomonas vaginalis and other microorganisms in 18-45 age group women. Turkiye Parazitol Derg 2012;36(3):182-4.

7. Akarsu GA. Investigation of Trichomonas vaginalis in patients with nonspecific vaginal discharge. Turkiye Parazitol Derg 2006;30(1):19-21.

8. Ertabaklar H, Ertuğ S, Kafkas S, Odabaşı A.R, Karataş E. Vajinal akıntılı olgularda T.vaginalis araştırılması. Türkiye Parazitol Derg 2004;28(4):181-4.

9. Çelik A, Atılgan R, Aygün HB, Özkan ZS, Can B, Kavak SB ve ark. Serviko-vajinal pap smear taramasında Trichomonas vaginalis, Candida ve Gardnerella vaginalis sıklığının yaşa göre değerlendirilmesi. Fırat Tıp Derg 2013;18(1):44-7.

10. Hobbs MM, Seña AC. Modern diagnosis of Trichomonas vaginalis infection. Sex Transm Infect 2013;89(6):4348.

11. Riley DE, Roberts MC, Takayama T, Krieger JN. Development of polymerase chain reaction-based diagnosis of Trichomonas vaginalis. J Clin Microbiol 1992;30:465-72. 
12. Özcel MA, Zeyrek FY. Trichomoniosis, pp: 431-47. In: Özcel MA (eds). Özcel'in Tıbbi Parazit Hastalıkları. 2007, Meta Basım, İzmir.

13. Lord E, Newnham T, Dorrell L, Jesuthasan G, Clarke L, Jeffery K, et al. Detecting asymptomatic Trichomonas vaginalis in females using the $\mathrm{BD}$ ProbeTec ${ }^{\mathrm{TM}}$ Trichomonas vaginalis $\mathrm{Q}(\mathrm{x})$ nucleic acid amplification test. Int J STD AIDS 2017;28(4):357-61.

14. Sonmez C, Usluca S, Hakki Usluca I, Kalipci I, Sezen F, Resat Atalay C, et al. Evaluation of symptomatic patients with resistant discharge. Acta Dermatovenerol Croat 2018;26(1):1-7.

15. Yentür Doni N, Aksoy M, Şimşek Z, Gürses G, Hilali NG, Yıldız Zeyrek F, et al. Investigation of the prevalence of Trichomonas vaginalis among female Syrian refugees with the complaints of vaginitis aged between 15-49 years. Mikrobiyol Bul 2016;50(4):590-7.

16. Karaman U, Atambay M, Yazar S, Daldal N. Kadınlarda Trichomonas vaginalis'in çeşitli sosyal değişkenler açısından yaygınlığının incelenmesi (Malatya ili örneği). Turkiye Parazitol Derg 2006;30(1):11-5.

17. Akyıldız F, Özçelik S, Özpınar N, Karakuş S. Vajinit ön tanılı kadınlarda Trichomonas vaginalis sıklığının araştırılması ve tanısında üç farklı kültür yönteminin karşılaştırılması. Turk Hij Den Biyol Derg 2018;75(1):43-52.

18. Doğan N, Gitmez F. Eskişehir'de kadınlarda Trichomonas vaginalis görülme sıklığının farklı yöntemlerle araştırılması ve çeşitli sosyal değişkenlerle olan ilişkisinin değerlendirilmesi. Osmangazi Tıp Dergisi 2019;41(1):4657.

19. Heine RP, McGregor JA. Trichomonas vaginalis: a reemerging pathogen. Clin Obstet Gynecol 1993;36:13744.

20. Patil MJ, Nagamoti JM, Metgud SC. Diagnosis of Trichomonas vaginalis from vaginal specimens by wet mount microscopy, in pouch Tv culture system and PCR. J Glob Infect Dis 2012;4(1):22-5.

21. Van Der Pol B, Williams JA, Fuller D, Taylor SN, Hook EW III. Combined testing for chlamydia, gonorrhea, and Trichomonas by use of the BD Max CT/GC/TV assay with genitourinary specimen types. J Clin Microbiol 2017;55(1):155-64.

22. Bagnall P, Rizzolo D. Bacterial vaginosis: a practical review. JAAPA 2017;30(12):15-21.

23. Kanbur S. Cinsel yolla bulaşan hastalıkların taranması ve tedavi protokollerinin karşılaştırılması. Zeynep Kamil Tıp Bülteni 2018;49(1):15-20.

24. Kaymak Y, Paşaoğlu A, Erhan M, Çelik B. Polikliniğimize vajinit yakınmasıyla başvuran hastalarda vajinal akıntı etkenlerinin araştırılması. Gazi Tıp Dergisi 2005;16(3):114-20.

25. Döğen A, Durukan H, Güzel AB, Oksüz Z, Kaplan E, Serin MS, et al. Genotyping of vaginal Candida glabrata isolates using microsatellite marker analysis and DNA sequencing to identify mutations associated with antifungal resistance. Mikrobiyol Bul 2013;47(1):109-21.

26. Ortaylı N, Sahip Y, Amca B, Say L, Sahip N, Aydın D. Curable sexually transmitted infections among the clientele of a family planning clinic in Istanbul, Turkey. Sex Transm Dis 2001;28(1):58-61.

27. Açık Y, Güngör L, Aşçı Toraman Z. İsteğe bağlı düşük yapmak için başvuran kadınların serviksinde bulunan bazı patojen mikroorganizmaların prevalansı ve klinik önemi. Erciyes Med J 2004;26(2):55-61.

28. Eksi F, Dikensoy E, Gayyurhan ED, Balci I, Balat O, Karsligil T, et al. The prevalence of Chlamydia trachomatis and Neisseria gonorrhoeae in the endocervical swab specimens of symptomatic, asymptomatic and infertile women in Turkey. Arch Gynecol Obstet 2011;283(6):1349-55.

29. Zarakolu P, Yağcı S, Çakır B, Ünal S. Screening for Chlamydia trachomatis infection using direct fluorescein antibody method in female sex workers registered in Ankara, Turkey: pros and cons. Turk J Med Sci 2009;39(1):81-4.

30. Külah C, Yumuşak M, Bayar Ü, Aktaş E, Cömert FB. İnfertil hastaların endoservikal örneklerinde Chlamydia trachomatis DNA'sının araştırılması. Türk Mikrobiyol Cem Derg 2009;39(1-2):44-7. 